\title{
SZÉKELY LEVENTE
}

\section{Információgazdaság}

\section{Szerzői információ:}

\section{Székely Levente}

$\mathbf{0}$

Szociológus és statisztikus az ELTE Társadalomtudományi és Bölcsészettudományi Karán végezte tanulmányait. Jelenleg a Budapesti Corvinus Egyetem doktori programjának hallgatója. 2005 óta a Budapesti Múszaki és Gazdaságtudományi Egyetemen múködő Információs Társadalom és Trendkutató Központban (ITTK) dolgozik kutatóként. E folyóirat konferenciarovatának és az Infinit hírlevél „Tudomány és technológia” címú rovatának szerkesztôje. Kutatási területei: kultúrafogyasztás, médiafogyasztás, új média, ifjúságügy, oktatásügy, információs társadalom. E-mail: szekely.levente@ittk.hu

Így hivatkozzon erre a cikkre:

Székely Levente. „Információgazdaság”.

Információs Társadalom VII, 4. szám (2007): 146-154

https://dx.doi.org/10.22503/inftars.VII.2007.4.9

A folyóiratban közölt müvek

a Creative Commons Nevezd meg! - Ne add el! - Így add tovább! 4.0

Nemzetközi Licenc feltételeinek megfelelően használhatók. 


\section{OLVASÁS KÖZBEN}

Székely Levente

In formációgazdaság ${ }^{1}$

\section{Bevezetés}

Szabó Katalin és Hámori Balázs „Információgazdaság - Digitális kapitalizmus vagy új gazdasági rendszer?" címú könyvükben arra vállalkoznak, hogy átfogóan mutassák be tárgyukat, az információgazdaságot, illetve azt az utat, amely az ipari kapitalizmustól az új gazdasági szerkezet kialakulásáig vezetett. Mindezt az új institucionalista gazdaságtani irányzat (institutional economics) szempontrendszere szerint teszik.

Az információgazdaság összefüggő rendszerként jelenik meg a könyvben. Szerzói szerint paradigmaváltás korszakát éljük: napjainkban az ipari kapitalizmusból az információgazdaság viszonyrendszereibe való átmenet zajlik valamennyi szférában. Ennek az átmenetnek még csak az elején tartunk, ugyanis egyelốre még a legfejlettebb régiók gazdasága sem alakult át teljességében az új szabályok szerint, ugyanakkor egyre több területen - különbözó mértékben - már hatnak az új viszonyok. Ez az elméleti alapvetés ellenkezik Manuel Castellsnak, az információs társadalom teoretikusának álláspontjával, miszerint az ,információs társadalomnak” már kialakult gazdasági rẹndszere van: a könyv szerzói az információgazdaságot nem megszilárdult gazdasági rendszernek, hanem úgynevezett átmeneti vagy „tranzíciós” gazdaságnak tekintik.

\section{Információgazdaság - kihívás a közgazdaságtan számára}

Az alapvetố probléma abban áll, hogy a közgazdaságtan tárgykörébe a szúkösen rendelkezésre álló, éppen ezért kisajátítható erőforrások tartoznak, ezzel szemben az információt, a tudást a klasszikus értelemben nem lehet kisajátítani. Napjainkban a digitalizált információ és a tudás képezik a gazdaság fớ mozgatóerejét, ezekre pedig sablonszerúen nem alkalmazhatók a szúkös eróforrásokra kidolgozott tételek.

Mivel a gazdaságot már egyre kevésbé a hagyományos tókeelemek (pl. gépek) határozzák meg, és ezek helyébe egyre inkább az emberi tudás, a digitális térben áramló információ lép, a korlátozott anyagi eróforrások cseréjén alapuló közgazdasági modellek változtatás nélkül nem alkalmasak az új rend vizsgálatára. Míg a hagyományos közgazdasági elméletek a javak kisajátíthatóságára építenek, addig az információt nem lehet kisajátítani, hiszen az információ átadása nem jelenti egyúttal az elveszítését. A szellemi természetû, digitális formában megjelenő ,javak" esetében a szúkösség fogalma nehezen vagy egyáltalán nem értelmezhetoo, hiszen ezeknek a javaknak az újratermelése gyakorlatilag nem jár költséggel. Ugyanakkor tény, amire a szerzók is felhívják a figyel-

\footnotetext{
${ }^{1}$ Szabó Katalin - Hámori Balázs (2006): Információgazdaság: Digitális kapitalizmus vagy üj gazdasági rendszer? Budapest, Akadémiai Kiadó.
} 
met, hogy az eredeti szellemi termék létrehozása (legyen szó akár egy új gyógyszermolekuláról, akár egy nanotechnológiával előállítható újfajta anyagról vagy például egy lexikonról) horribilis beruházásokat és ráfordításokat követel. A közgazdaságtani szemlélet szerint abban az esetben, ha bôség van valamely jószágból, arra nézve nincs értelme tulajdonjogot definiálni. Ugyanakkor, mint az élet bizonyítja, lehetőség van arra, hogy a szellemi termékek esetében mesterséges úton, jogi intézmények segítségével próbálják megteremteni a szúkösséget, már csak azért is, hogy biztosítsák az említett óriási ráfordítások megtérülését.

A szerzók véleménye szerint ma már majdnem minden termék részben „tudásjószág" is, hiszen a közönséges termékek értékének nagy részét a bennük tárgyiasult tudás adja. A dematerializálódás és a virtualizálódás tendenciája hatja át a gazdaságot. A dematerializálódás jelentôségét mutatja, hogy az úgynevezett „fejlett világban” az egységnyi GDP elóállításának költsége az 1970-es és 80-as években évi két százalékkal csökkent.

A közgazdaságtan sokszor kerül kutyaszorítóba az információgazdaság és az immateriális javak vizsgálata során. Nem csupán a használható elméletek és modellek hiányoznak sok esetben, hanem gyakran még az új jelenségek sincsenek megnevezve. A szerzók szerint leginkább az ún. institucionalista megközelítés alkalmas az új jelenségek leírására. Ennek az új irányzatnak az az előnye, hogy a szúk közgazdaságtani megközelítéssel szemben - amely kizárólag a racionális döntések szerepére épít - teret enged a mintakövetés, a tanulás és a piacon kívüli intézmények érvényesülésének is. Ezzel a szemlélettel könnyebb megérteni az olyan - a közgazdaságtan számára kezelhetetlen - jelenségeket, mint amilyen például a szellemi termékek minóségének és mennyiségének ,paradox” összefüggése, ami lehetôvé teszi, hogy a jobb minôségú termékek gyakran egyben olcsóbbak is legyenek. Hasonló példát nyújt az is, hogy a szoftveriparban nem az egyedi termékek, a ritkaságok hordozzák az értéket, hanem azok, amelyek a legelterjedtebbek.

Szabó Katalin és Hámori Balázs könyve az említettek mellett még számos más, az információgazdaság újfajta viszonyai között kialakult sajátos jelenségre is felhívja a figyelmet. Az információgazdaság bemutatásában a szerzók teljességre törekszenek, így a rendszerlogika megváltozásán túl bemutatják a termékek, a tranzakciók, a fogyasztók és a vállalatok szerepét, valamint a szereplók viselkedésének a sajátosságait a megváltozott gazdasági környezetben.

\section{A meguáltozó rendszer}

Az információgazdaság belső viszonyait Szabó és Hámori a korábbi gazdasági szerkezetból kiindulva vezeti le, számos konkrét példával könnyítve meg az olvasó dolgát. Bemutatják, milyen látható jelei vannak az információgazdaságnak, és honnan vezetett az út idáig.

Az időalapú verseny általánossá válásával, a gyorsaság felértékelődésével a vállalatok egyre nagyobb termékválasztékot dobtak piacra, egyre gyorsuló ütemben. A gyors reagálás elsődlegesen fontossá vált: a termékek életét és egyben az előállításukból és forgalmazásukból nyerhetố profitot is jelentốsen befolyásolja, hogy a termékek a kifejlesztésüktól számítva milyen gyorsan kerülnek piacra, valamint az is, hogy a vállalatok 
milyen súrû́n frissítik termékpalettájukat. Míg az utolsó „,bogárhátú” Volkswagen az elsố után hatvan évvel gördült le a futószalagról, az autógyárak ma már 3-4 évente vagy még súrúbben újítják meg a típusaikat. A gyorsaságra jó példa, hogy egy percen belüli hitelbírálat már Magyarországon is elérhető, míg ugyanez Japánban ma mindössze 10 másodpercet vesz igénybe. Az idősebbek még emlékezhetnek arra, hogy hány hónapig tartott a régi idókben, amíg a felvenni szándékozott hitelre vonatkozóan döntést csikartak ki a banktól.

Az információs társadalom jellemzóje továbbá a megváltozott térszemlélet is: a konkrét terek jelentősége csökken. Az infokommunikációs eszközök alkalmazása a gazdaságban lehetôvé tette a helyhez kötöttség fokozatos megszüntetését és a termelési folyamatok decentralizációját. Az idốt és a teret a vállalatok ma már nem a termelési folyamatok hagyományos kereteiként, hanem változtatható paraméterekként értelmezik, és kreatívan bánnak velük. Érzékelhetố ugyanakkor egy ezzel ellentétes folyamat is, nevezetesen a tér felértékelődése az úgynevezett high-tech klaszterekben - erre talán mindmáig a Szilícium-völgy a legjobb példa.

Az „összemosódást” nem csupán a korábban megváltoztathatatlan adottságnak tekintett térbeli és idóbeli határok viszonylagossá válásában, hanem a technológiák egybeolvadásában is tetten érhetjük, és a vállalatok hálózatosodásában is ugyanez a tendencia érvényesül. Az információs társadalom gazdasági szerkezetét hálózati gazdaságnak is szokás nevezni. Ez a megnevezés arra utal, hogy a termékek és szolgáltatások létrehozása, maga az értékteremtés hálózatokban történik, a hálózatok múködésének a sikere pedig attól függ, hogy az új társadalmi-gazdasági környezetben képesek-e hatékonyan tudást létrehozni és információt feldolgozni, és tudnak-e rövid időn belül alkalmazkodni a gyorsan változó globális körülményekhez, eszközrendszerüket rugalmasan hozzáigazítva a megváltozott viszonyokhoz (Castells 1996). ${ }^{2}$

\section{A termék}

Az információgazdaságban a hagyományos termékszemlélet is átlényegül. A termelésben visszaszorulóban van a tömeggyártás, az ún. fordizmus, és terjed a termékek testre szabása. Ismét fontossá válik az egyéni ízlések kielégítése, azaz a fejlett technológia világában újra divatba jönnek a gyakran globális hálózatokba szerveződött „úri szabók". A tökéletes testre szabás leginkább az információtechnológia területén terjed (különféle speciális számítógép-konfigurációk ma már szinte mindenütt összeállíthatók egyéni kívánságok szerint), de - szintén az információs technológiának köszönhetốen számos másféle termék is testre szabható. A testre szabhatóság megvalósulásában az igények felmérésétól a termék elkészítéséig mindvégig nagy szerepet játszanak az információs technológiák. (Az egyéniesített, személyre szabott termékek rontják a fogyasztók lehetôségeit az összehasonlításra.) Az egyéniesítés ugyanakkor nem mond ellent a szabványosításnak, hiszen a testre szabott termékek egységes modulok különféle

\footnotetext{
${ }^{2}$ Castells, Manuel 2005. Az információ kora - Gazdaság, társadalom és kultúra. I. kötet: A hálózati társadalom kialakulása. Bp., Gondolat Kiadó.
} 
kombinációiból jönnek létre: erre a szerzók számos példát hoznak a legkülönbözóbb ágazatokból, a bankszektortól az autóiparon át a telekommunikációs szolgáltatásokig.

A termékek testre szabása egyben azt is jelenti, hogy egyre jobban elmosódik a határvonal a termék és a szolgáltatás között. A 20. században általánosan elfogadott volt a szolgáltatások következő meghatározása: „ami nem mezốgazdaság és nem ipar, az szolgáltatás”. Ma ez a maradékelvú szemlélet már nem tartható fenn, hiszen a szolgáltatások nem afféle „,kiegészítô szektort” alkotnak, hanem a gazdasági élet középpontjába kerültek. A szolgáltatások értéknövelő hatást fejtenek ki a termékekre és a nyersanyagokra is. A csere és a fogyasztás alapjait ma már nem lehet a termékek és szolgáltatások dichotómiájával megragadni, mert harmadik tényezóként egyre jelentốsebb szerephez jutnak a szellemi termékek. A szerzók idézik Robert Fogelt, aki szerint az Egyesült Âllamokban a fogyasztásra fordított idő és pénz kétharmada a szórakozás és a szabadidôs tevékenységek céljait szolgálja.

Az anyagi formában is megtestesülố tudásjószágok (pl. egy zenei CD) esetében egyrészt szúkős erôforrásokkal létrehozott, másrészt végtelenül replikálható szellemi terméket vásárolunk, s ennek következtében a termék értéke két részból áll: egy anyagi és egy szellemi komponensból. Majdnem minden tudásjószág úgynevezett „tapasztalati termék" lesz, amelynek a hasznosságát a vásárlás elótt nem tudjuk megítélni, és amely a materiális összetevókön kívül jelentôs szellemi hozzájárulást tartalmaz.

A cégek sikeressége nem csupán a megfelelő árú és minőségú termékek függvénye, a fogyasztók szemében egyre fontosabbá válik a vállalkozások (és dolgozóik) etikai és kommunikációs viselkedése. Az információ korában az információbőség olyan szintre ért, hogy megjelent egy újfajta szúkösség, nevezetesen a figyelem szúkössége. A figyelem döntő fontosságú az új gazdaság számára: a cégeknek sokszor nem elsősorban a fogyasztók pénzéért, hanem a figyelmükért kell megküzdeniük. Ebben a világban a vállalat fizet a vevónek azért a figyelemért, amit az a vállalatra fordít.

\section{Tranzakciók}

Az információgazdaság virtuális tranzakciós tereiben (e-kereskedelem) elôtérbe helyeződik a bizalom és a kooperáció kérdése. Bizalomhiány kialakulásához vezethet, ha egy meghatározott vevố-eladó páros közötti tranzakciók száma csekély (ugyanaz a vásárló, ugyanazzal az eladóval nem súrún találkozik), a virtuális tranzakciós terekben továbbá az identitás (személyes) változtathatására is lehetôség van (ennek legdurvább fajtája az identitáslopás). Az infokommunikációs technológiák és különösen az internet által biztosított (kommunikációs) terekben ugyanakkor közösségek szervezódnek, amelyek megkerülhetetlen szerepet játszanak a termékek vagy a vállalatok értékelésében. Így alapjaiban megrendül a vevók egymástól való elszigeteltségén alapuló korábbi kommunikációs aszimetria, és a vevók és az eladók között egészen más viszony alakul ki, mint az offline kereskedelemben. A termékek véleményezési lehetôségének biztosítása a vevók számára összességében csökkenti az ismerethiányt, s ebból adódóan megoldást nyújthat a bizalomhiány leküzdésére.

Az információgazdaságban átalakul a marketing szemlélete: a központi kérdés többé nem az, hogy a termelő mit kinál a fogyasztónak, és még csak nem is az, hogy a ve- 
vốknek milyen termékekre van szükségük, hanem az igények kerülnek előtérbe. Az eladóknak a vevô jövóbeli igényeit kell kitalálniuk. A siker kulcsa az, hogy a vállalatok ne a vásárlók tömegeit, hanem az egyéneket vegyék célba és kínálatukat gyorsan az igényekhez tudják hangolni. A marketing központjában ma már nem a termék (illetve a termeló) áll, hanem a vállalat és a fogyasztó közötti kapcsolat. A marketing lényege változik meg: nem az lesz a központi kérdés, hogy a vállalat mit akar eladni, hanem az, hogy a vásárló mit akar venni.

A logisztikában is áttevôdik a hangsúly: a mennyiségnél fontosabbá válik a sebesség és a kereslet változásaihoz való rugalmas alkalmazkodás. A hagyományos módon múködô kereskedések csillaga leáldozott. Ugyanakkor a lehetôségek egész tárháza nyílt meg olyan új megoldások elốtt, mint például a termékek kiszállítása közvetlenül a fogyasztóhoz, vagy a logisztikai költségek megosztása a vevố és az eladó között.

Az internet kitúnố tranzakciós tér, amely természetéból adódóan megkívánja az elektronikus fizetőeszközöket. Mára az elektronikus pénzügyi eszközök használata széles körben elterjedt a hétköznapokban, $s$ a kevésbé fejlett országokban éppen a pénzvilág az informatizálás motorja. A pénz kiválóan alkalmas digitalizálásra, ugyanis elvont áru, értéke nem köthetố materiális megjelenéséhez. A bankok is elektronizálták belsố múködésüket, ATM-eket telepítettek, rugalmasabbá tették szolgáltatásaikat. A változások éllovasának számító pénzintézetek mellett is megjelentek azonban a külsô versenytársak. Egyes internetes kereskedések ugyanis - fóleg a kisösszegú kifizetések terén - kikerülik a bankok szerepét a fizetési múveletekben (pl. a PayPal).

A minőség és a mennyiség összefüggése is megváltozott: a szellemi termékek esetében a minőség sokkal tágabb határok között mozog, mint a materiális termékeknél, s ugyanakkor nehezebb is megítélni. A szúk körben terjesztett javak az úgynevezett „elsüllyedt költségek" miatt általában veszteségesek. A szellemi termékek esetében az ingyenesség és a kipróbálhatóság is más logika alapján múködik, mint az anyagi természetû társaiknál. A „tapasztalati termék” ingyenessége valójában nem jelent pótlólagos költségeket a vállalat számára, mert az ingyenesség, illetve a jogtalan másolás rövid távon csökkenti ugyan a bevételeket, de hosszabb távon ez a hatás leggyakrabban az ellenkezôjére fordul. Erre kitúnő példa a Skype ingyenes internetes telefonálást biztosító szoftver. Az ingyenes programot - miután felhasználóinak a száma több tízmilliós szintre ért - megalkotói eladták az eBay-nek 4,2 milliárd (!) dollárért. (Itt nyilván a felhasználók tömegei, az adatbázisban rejlő lehetôségek az igazán értékesek, nem pedig maga a program.)

$\mathrm{Az}$ információgazdaság piaca egyes tulajdonságaiban emlékeztet a régmúlt idók cserekereskedésére. Az elektronikus piactereken alkalmazhatók az alkudozás különféle, már-már elfeledett válfajai, az információgazdaság ugyanis aligha egyeztethetô össze a statikus árazással. A térbeli és idóbeli korlátok megszúnése azt hozta magával, hogy a teljes választék megismerése (az árak összehasonlítása) soha nem volt olyan könnyú, mint ma, s ez a lehetôség természetszerúleg lefelé nyomja az árakat. Ugyanakkor szó sincs a fogyasztók királyságának eljöveteléról, mert ebbe a nagyvállatok is bele kívánnak szólni. Intelligens szoftvereik kiszimatolják, milyen vastag a fogyasztó pénztárcája, s így olyan árakat tudnak kínálni (akár személyre szabottan), ami a fogyasztónak még éppen megéri. A vállalatok részéról a nagyobb bevétel érdekében leggyakrabban alkalmazott stratégiák a következók: a fogyasztók elszigetelése, az árak személyre szabása és 
az árukapcsolás. Ezt a logikát követi a „tapasztalati termékek” árképzése is, ahol nem a termelésre fordított költségek (ami gyakran nullával egyenlô), hanem a fogyasztók értékítélete alapján történik. A fogyasztóknak is vannak azonban ütókártyáik: az információgazdaság hálózati jellege lehetốséget ad a csoportos vásárlásra (sok kisfogyasztó összefoghat és vásárlásainak összehangolásával „nagyként” jelenik meg a vállalat szemében, s így előnyösebb árat tud kialkudni), ami a vállalat számára is előnyös lehet.

A kisfogyasztók egyre nagyobb jelentôségét mutatja Chris Anderson könyve is (The Long Tail), amelyról Bógel György ${ }^{3}$ így ír a blogjában: „Chris Anderson szerint a modern információs technológia, az internet, a világháló nekik [mármint a kisfogyasztóknak, Sz. L.] dolgozik.” Bőgel, Anderson nyomán, a piacot fekvố kígyóhoz hasonlítja, amelynek feje magasra emelkedik. Ez „a magasra emelkedő fej jelképezi a slágertermékeket: viszonylag kevés van belólük, viszont nagyon nagy a forgalmuk". A kígyó farka a speciális (ritka, változatos) termékeket jelképezi, amelyek egyedi tulajdonságaik miatt csak keveseket érdekelnek. Az utóbbiak esélyei eddig rosszak voltak, ugyanakkor az informatika fejlődésének következtében a digitális formában levô termékeket egyszerû és könnyú tárolni és értékesíteni. Bôgel szavaival élve: „a honlapok, az internetes kereskedelem, az elektronikus bolhapiacok, fórumok, az egyre kifinomultabb internetes keresốszolgáltatások, az e-csatornákon megmozgatott kollektív intelligencia segítségével össze lehet gyújteni és ki lehet szolgálni a szétszórt vevoóket, kicsi piacocskákat. Ami eddig nem volt az, most láthatóvá, elérhetővé, életképessé, gazdaságossá válhat. A kígyó farka meghosszabbodik, megvastagszik, megemelkedik. Nagynak lenni változatlanul jó, de a kicsiknek is szépen javulnak az esélyei. A modern technológia színesebbé, tarkábbá, egyedibbé teszi a világot.”

Az információgazdaság - a várakozásokkal ellentétben - nem hozta el a tökéletes verseny állapotát, bár a piacra lépést az internet megjelenése megkönnyítette, és a monopolhelyzetet sokkal nehezebb megtartani ma, mint korábban. Megjelentek azonban a versenyt korlátozó új tényezók is. Ezek közé tartozik az ún. „bennragadás” (lock-in), ami azt jelenti, hogy valamely technológiát csak azért alkalmaznak még mindig, holott már létezik jobb megoldás, mert korábban nagy tókét fektettek bele (megvettek egy berendezést, megtanulták egy bonyolult program kezelését stb.); továbbá az információs kaszkádok (döntési láncok) érvényesülése, ami abban nyilvánul meg, hogy mások döntései alapján döntünk, és nem mi magunk ítéljük meg a termék alkalmas voltát (az emberek szeretik utánozni egymás viselkedését); valamint a versenyt korlátozó szabványháborúk is (az információgazdaságban inkább nagyobb termékrendszerek, mintsem pusztán termékek versenye folyik).

Korábban az ipari gazdaságban a termelés nagy költségekkel járt, s így a nagyvállalatok jelentốs elốnyben voltak, az információgazdaságban viszont a piacra lépés költsége jóval alacsonyabb, ami élezi a versenyt, ${ }^{4}$ s ennek következtében a kis cégek is be tudnak kapcsolódni a globális versenybe. Az információgazdaságban ugyanakkor növeked-

\footnotetext{
${ }^{3}$ http://www.kfki.com/blog_1F71AD83C0D449D395C9D5D0D6595BE1.php?blogId=864\%234 Letöltés ideje: 2007.09 .01

${ }^{4}$ A nagyfokú piaci verseny azzal jár, hogy a szereplók sokszor „egészségtelen” munkaterhelést kénytelenek elviselni.
} 
nek a tétek: míg korábban egy olyan vállalatnak, amely alulmaradt a versenyben, általában csupán kisebb nyereséggel kellett számolnia, ma viszont a vesztest sokszor a kiszorulás és a teljes megsemmisülés veszélye fenyegeti. Mindez a „monopólium - verseny-monopólium - verseny" ciklikus rendszerének, bizonyos körforgásnak a kialakulásához vezet: ma már nem gyakoriak a hosszú távra berendezkedő monopóliumok. Ma tehát korántsem a tankönyvi tökéletes verseny, hanem újfajta piaci formák megvalósulását látjuk. A verseny ma az innovációkra alapozott schumpeteri verseny formáját ölti: rövid távon az elsóség az ár/teljesítmény viszonyából származik, míg hosszú távon a siker alapja az alapvetố versenyelőnyök olcsóbb és gyorsabb létrehozása.

\section{Vállalatok és fogyasztók}

$\mathrm{Az}$ információtechnológia alapvetóen átrendezi a vállalati világ múködését, szervezeti felépítését és magatartását egyaránt. A 20. század elején a vállalati vagyon még többnyire valamilyen természeti kincs birtoklásán vagy a pénztôkén alapult, majd a 70-es évektôl kezdődően beindult egy olyan folyamat, melynek során a vállalatok vagyonának egyre nagyobb részét az ún. megfoghatatlan tóke (intangible assets) teszi ki, melynek az elótérbe kerülése megváltoztatja a vállalat múködésének egészét. Ez az átalakulás ugyanakkor számos mérhetôségi és elméleti jellegú problémát is felvet, hiszen a megfoghatatlansághoz bizonytalanság is társul. Ráadásul érvényesül az a paradoxon is, hogy minél jelentósebb a megfoghatatlan tốke egy vállalat életében, annál nehezebb meghatározni a mértékét. Szabó és Hámori a Nokia 2000. évi mérlegén keresztül szemléltetik a megfoghatatlan tóke szerepét. Míg a Nokia „látható tốkéje” (gépek, irodák stb.) összesen csupán 5,7 milliárd dollárra rúg, a cég piaci értéke körülbelül 190 milliárd dollárra tehető, vagyis ebból mintegy 184 milliárd dollárnyi értéket a megfoghatatlan tóke - a márkanév, az innovációs potenciál, a vállalat dolgozóinak szakmai tudása stb. - tesz ki.

A megfoghatatlan tókéhez igazodó információgazdaság felülírja a hagyományos munkamegosztást: az információgazdaságnak kevesebb, ugyanakkor nagyobb tudású munkavállalóra van szüksége. A munkavállaló számos szegmensben már nem pusztán csavar a gépezetben, hanem elvárják tóle, hogy a folyamatok jobbításán munkálkodjon, ami nélkülözhetetlen a rugalmasság kívánalmának teljesítéséhez. A rugalmasság nem pusztán kifelé mutatkozik meg, hanem a szervezeten belül is megjelenik, teret engedve a rugalmasan változó összetételú, többé-kevésbé önirányító csoportok összehangolt csapatmunkával elért teljesítményeinek.

Az információgazdaság kihívásának megfelelni vágyó vállalatok leépítik korábbi merev, hierarchikus szervezetüket, és helyette rugalmas hálózati struktúrákat alakítanak ki. A hálózat erejét az adja, hogy a tagok kétoldalú kapcsolatai a hálózatba ágyazottak. Minden hálózat értéke a nagyságától függ: minél nagyobb egy hálózat, annál értékesebb.

A hálózati termelés legkiválóbb példái a multinacionális vállalatok, ${ }^{5}$ amelyeknél gyakran előfordul, hogy a cégnek a székhelye, a $\mathrm{K}+\mathrm{F}$ részlege és a gyártósorai különbö-

${ }^{5}$ A legerôsebb hálózatok az információtechnológia területén jöttek létre, ami leginkább a hardver- és a szoftveripar nagyfokú egymásrautaltságának köszönhető. A 20. század végén több nagyvállalat (például a Cisco Systems vagy a Nokia) elsốsorban az új hálózati múködési módon alapuló gazdasági modellnek köszönhette versenyelönyét és sikereit. A kilencvenes évek végétól egyre több informatikai profilú cég (többek között a 
zố országokban vagy akár különböző földrészeken találhatók. Ahhoz, hogy a vállalkozás ki tudja használni a hálózat rugalmasságát, saját magának is hálózattá kell válnia. A hálózati múködés nem csupán területileg, hanem szervezetileg is megjelenik. A multinacionális vállalatok vertikális szervezeti modellje átalakult, és ma az „óriások” kisebb vállalatok sokaságára támaszkodva töltenek be domináns szerepet a hálózatokban, a kisebbeket legtöbbször a „,kiszervezés” (outsourcing) ${ }^{6}$ módszerének alkalmazásával láncolva magukhoz. Megjelennek a nagyvállalatok közötti stratégiai szövetségek is, amelyeknek a lényege az „együttmúködő versengés” (kopetíció). A kopetíció különösen fontos a nagy kutatási és beruházási költséggel múködőhigh-tech vállalatoknál, pl. a közösen elfogadott szabványok esetében.

A vállalati filozófia megváltozása tetten érhetố a vállalatok önmagukról kialakított képében is. Míg az ipari korszakban a vállalatot mintegy „gépezetként” képzelték el, addig az információs kor vállalati képében már az önszerveződés, ,a természet utánzása" dominál. Az új elgondolások elméleti szinten is megjelentek. A vállalatelméletben bár korábban is szerepet kapott az evolucionista szemlélet, azonban csak az információs korszakban érett paradigmává, tekintélyes tudományos iskolát létrehozva.

A vállalat abból a célból is kénytelen biztosítani a szervezet rugalmasságát, hogy részlegeit szükség esetén, a piac kihívásaira reagálva pillanatok alatt képes legyen átszervezni. Ennek következtében, valamint a „szétszórt” hálózati termelés hatására csökken a stabil munkahelyek száma, a fordi tartós foglalkoztatás modelljét felülírta az információs kor. Egyre nagyobb teret kapnak az atipikus foglalkoztatás különböző formái, köztük a munkaerô-kölcsönzés és a távmunka is. A statikus, kötött formák képlékennyé, gyorsan megváltoztathatóvá, „eloldozottá” válnak. A tudást és a szakmai készségeket nagyra értékelő információgazdaságban nomád munkavállalók vándorolnak vállalatok, országok, földrészek és különféle projektek között, ami tovább erôsíti a munka világában kialakult bizonytalanságot. Ugyanakkor a tudás elótérbe helyezése újfajta egyenlốtlenségeket generál: ilyenek például az infokommunikációs eszközök használatához kapcsolódó tudás terén mutatkozó generációs különbségek.

A fogyasztói magatartás is változóban van: az internet adta lehetőségek kihasználásával a fogyasztók képesek lényegesen lecsökkenteni tranzakciós költségeiket, szinte teljesen függetleníteni tudják magukat a helytól és az idoótól, és ezt meg is teszik. Az információgazdaság fogyasztóját a tájékozottság, a kényelemszeretet és egyben a türelmetlenség is jellemzi: csupa olyan tulajdonság, amely a vállalat szempontjából nem előnyös. Egyrészt a gyorsan és gyökeresen változó technológia, másrészt a vásárlók sokszor bizonytalan preferenciái miatt az új piacokon nem alakul ki egyensúlyi helyzet, így a vállalatok számára kiemelkedốen fontos, hogy megtartsák meglevő vevóiket, akikre éppen ezért sokkal jobban figyelnek, mint korábban.

A vállalatok az anyagi javakon túl különféle élményekkel vagy „életmód-generáló termékekkel" manipulálva is próbálják megragadni és fogyasztásra bírni potenciális vá-

Hewlett Packard, az IBM, a Sun Microsystems és az Oracle) kezdte meg múködésének átszervezését a hálózati elveknck megfelelôen, de a hagyományosabb, nem kifejezetten információtechnológiával foglalkozó vállalatok, köztük autógyárak, textilüzemek és bankok is sikeresen megpróbálkoztak a váltással.

${ }^{6}$ A vállalat vagy államigazgatási szerv különbözố tevékenységeinek kihelyezése más cégekhez. Leginkább olyan tevékenységeket szoktak „kiszervezni”, amelyek nem tartoznak a vállalat fó́ tevékenységi köréhez (core business). 
sárlóikat - ide sorolható többek között a mesterségesen táplált sztárkultusz is. A kiszámítható fogyasztói magatartás kialakítása érdekében alkalmazott stratégiák általában beválnak, annak ellenére, hogy az infokommunikációs eszközöknek, elsősorban az internetnek köszönhetốen a fogyasztók szerepe nem korlátozódik többé a passzív elfogadásra. A fogyasztóknak lehetốségük van beleszólni a termelésbe, amit a gyártók sokszor ki is használnak, mert ezáltal jobb termékekhez és költségmentes promóciós lehetôségekhez juthatnak.

\section{Összefoglalás}

„Nem a legerốsebb faj lesz a túlélő, nem is a legintelligensebb, hanem az, amelyik a leggyorsabban képes változni” - idézik a szerzók Darwint, és ez a mondat kitúnő mottó lehetne nemcsak könyvük, hanem az egész információgazdaság számára is.

Az információgazdaság „szellemére” rábukkanhatunk mindenütt, akár a vállalatok világát, akár a fogyasztói magatartást, a tranzakciókat vagy a munkavállalókat vizsgáljuk, bár maga a szellem is illékony és gyorsan változik. A gyors változások a közgazdaságtudományon belül is észlelhetôk. Más tudományágakhoz hasonlóan itt is érvényesül a multidiszciplinaritás felé mutató tendencia, és erre szükség is van, hiszen a rugalmasságra épüló információgazdaság megértéséhez a méróeszköznek is rugalmasnak kell lennie.

Szabó Katalin és Hámori Balázs könyve átfogó és rendkívül inspiráló mú, amelyben - Bốgel György szavait idézve ${ }^{7}$ - ,gazdag, színes körképet [...] festenek elénk: a termékekról, a tranzakciókról, a piacokról, a figyelemról, a bizalomról, a marketingról, a pénzrôl és az árakról, a versenyról, a szellemi vagyonról, a szervezetekrôl és a munkavállalókról, vagyis mi magunkról. Hatalmas tablót festenek, a maguk látószögéból, a maguk stílusában. Minden ízében vitára ingerlő könyv, vitatkozni is kell vele. Kell ennél jobb?"

${ }^{7}$ http://www.kfki.com/blog_20E118F23A9342AE9F538002B780A6F8.php?blogId=763\%23ebdc4a21 \&year=\&month= Letöltés ideje: 2007. 09. 01 